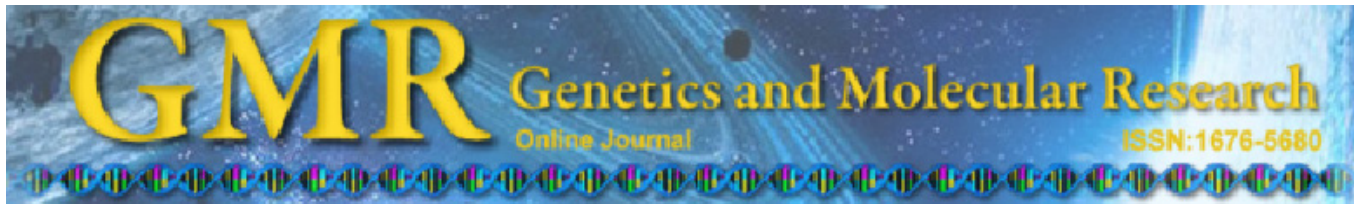

\title{
Karyotype diversity of four species of the incertae sedis group (Characidae) from different hydrographic basins: analysis of AgNORs, CMA3 and 18S rDNA
}

\author{
M.M. Mendes, R. da Rosa, L. Giuliano-Caetano and A.L. Dias \\ Departamento de Biologia Geral, Centro de Ciências Biológicas, \\ Universidade Estadual de Londrina, Londrina, PR, Brasil \\ Corresponding author: A.L. Dias \\ E-mail: anadias@uel.br
}

Genet. Mol. Res. 10 (4): 3596-3608 (2011)

Received March 21, 2011

Accepted August 31, 2011

Published November 22, 2011

DOI http://dx.doi.org/10.4238/2011.November.22.5

\begin{abstract}
A large number of genera in the tropical fish family Characidae are incertae sedis. Cytogenetic analysis was made of four of these species: Astyanax eigenmanniorum, Deuterodon stigmaturus, Hyphessobrycon luetkenii, and $H$. anisitsi, collected from various hydrographic basins: hydrographic system from Laguna dos Patos/RS, Tramandaí basin/RS and Tibagi River basin/PR. The first two species were collected in their type locality in the State of Rio Grande do Sul. The $2 n=48$ karyotype was observed only in A. eigenmanniorum, while the other species had $2 \mathrm{n}=50$ chromosomes, with different karyotypic formulas. There was weak heterochromatin staining in the pericentromeric region of $A$. eigenmanniorum, $D$. stigmaturus and $H$. luetkenni chromosomes. In $H$. anisitsi, heterochromatin appeared to be more abundant and distributed in the pericentromeric and terminal regions of the chromosomes; three pairs showed more evident heterochromatic blocks. There were multiple Ag-NORs in all populations, visualized by FISH with an $18 \mathrm{~S}$ rDNA probe. While $D$. stigmaturus and $H$. luetkenii
\end{abstract}


had conserved $\mathrm{AgNOR}, \mathrm{CMA}_{3}$ and $18 \mathrm{~S}$ rDNA sites, the other two species showed intra- and interindividual variation at these sites. The karyotype variability was high, as is common in this group of fish. Different species arising from isolated hydrographic basins maintain an elevated level of karyotype differentiation, mainly with respect to chromosome structure, heterochromatin distribution and rDNA localization. This is the first report with cytogenetic data for D. stigmaturus and H. luetkenii.

Key words: Chromosome banding; FISH; Karyotype variability; Topotypes

\section{INTRODUCTION}

The family Characidae shows the greatest diversity of the order Characiformes, with about 950 species of fish described (Reis et al., 2003). It comprises 13 subfamilies, where the majority of the genera are included in the subfamily Tetragonopterinae. While there is a lack of evidence that this subfamily is a monophyletic group, these genera have been placed in an incertae sedis group by Lima et al. (2003), based on phylogenetic systematics.

Of the 88 genera of the family Characidae belonging to the incertae sedis group, only $18,(20 \%)$, have been cytogenetically studied. Therefore, little is known about the karyotype structure of this group, and the literature is practically limited to the genus Astyanax (Baird and Girard, 1854), for which a wide numeric and morphologic variability is very evident (Pazza et al., 2006; Hashimoto et al., 2008; Kantek et al., 2008; among others).

Besides Astyanax, the genera belonging to the incertae sedis group, for which cytogenetic studies have been conducted are: Bryconamericus Eigenmann in Eigenmann (McAtee and Ward, 1907), Ctenobrycon (Eigenmann, 1908), Deuterodon Eigenmann in Eigenmann, (McAtee and Ward, 1907), Exodon (Muller and Troschel, 1844), Gymnocorymbus (Eigenmann, 1908), Hasemania (Ellis, 1911), Hemigrammus (Gill, 1858), Hollandichthys (Eigenmann, 1909b), Hyphessobrycon (Durbin in Eigenmann, 1908), Markiana (Eigenmann, 1903), Moenkhausia (Eigenmann, 1903), Nematobrycon (Eigenmann, 1911a), Oligosarcus (Günther, 1864), Piabina (Reinhardt, 1867), Prionobrama (Fowler, 1913), Salminus (Agassiz in Spix and Agassiz, 1829), and Triportheus (Cope, 1872b). The majority of these studies only refer to the diploid number, but have demonstrated karyotype variability, such as the occurrence of different cytotypes in the genus Bryconamericus (Paintner-Marques et al., 2002; Capistano et al., 2008), presence of B chromosomes in the genus Moenkhausia (Foresti et al., 1989; PortelaCastro et al., 2002), occurrence of sex chromosomes in the genus Triportheus (Nirchio et. al., 2007; Diniz et al., 2008), and different patterns of heterochromatin distribution in Oligosarcus (Rubert and Margarido, 2007; Hattori et al., 2007), among other examples.

The chromosome number in the species of this group varies from 36 in Astyanax schubarti Britski, 1964 (Morelli et al., 1983) to 54 in Bryconamericus sp (Wasko and Galetti Jr., 1998), where the diploid numbers 50 and 52 are the most constant. Portela et al. (1988) suggested that the ancestral karyotype of the old subfamily Tetragonopterinae, where the majority of its representatives belong currently to the incertae sedis group, bears $2 \mathrm{n}=50$ meta- and submetacentric chromosomes.

Besides the large karyotypic difference found in this group, different cytogenetic markers show the variation of species in the distribution of repetitive DNA sequences, such as 
the organization of heterochromatin, $18 \mathrm{~S}$ rDNA, $5 \mathrm{~S}$ rDNA, and different families of repetitive DNA (Ferro et al., 2000; Rosa et al., 2009).

Because of the remarkable chromosomal variability among the genera of the family Characidae, four species of this group were studied in the present study, focusing on both cytogenetic and molecular features, to investigate the genetic events that occur in populations from different hydrographic basins.

\section{MATERIAL AND METHODS}

Four species of the family Characidae listed as Incertae sedis were collected in three hydrographic basins: a) 11 specimens ( 9 females and 2 males) of Astyanax eigenmanniorum (Cope, 1894) from Saco da Alemoa (2959'39.49'S e 51 14'42.64”W) municipality of Eldorado do Sul/Hydrographic system from Laguna dos Patos/RS; b) 8 specimens ( 5 females and 3 males) of Deuterodon stigmaturus (Gomes, 1947) from Maquiné river (29 42'11.84"S e 50 11'48.09'W) municipality of Maquiné/Tramandaí basin/RS; c) 18 specimens of Hyphessobrycon luetkenii (Boulenger, 1887): 3 males collected from Saco da Alemoa (29 59'39.49"'S e $51^{\circ} 14^{\prime} 42.64^{\prime \prime} \mathrm{W}$ ) and 7 females and 8 of indeterminate sex collected in the Maquiné river ( $29^{\circ} 42^{\prime} 11.84^{\prime \prime S}$ e $50^{\circ} 11^{\prime} 48.09^{\prime}$ 'W) municipality of Maquiné/Tramandaí basin; and d) 13 individuals (6 males and 7 females) of Hyphessobrycon anisitsi (Eigenmann, 1907) collected in the Cambé stream (23 $19^{\prime} 09.38^{\prime \prime}$ S e $\left.51^{\circ} 11^{\prime} 44.72^{\prime \prime W}\right)$ municipality of Londrina/Tibagi river basin/PR (Figure 1). Individuals from each population were deposited in the Museum of Zoology at Universidade Estadual de Londrina (MZUEL) under the numbers, MZUEL 5070 to Astyanax eigenmanniorum; MZUEL 5086 to Deuterodon stigmaturus; MZUEL 5092 to Hyphessobrycon luetkenii; MZUEL 5216 to Hyphessobrycon anisitsi.

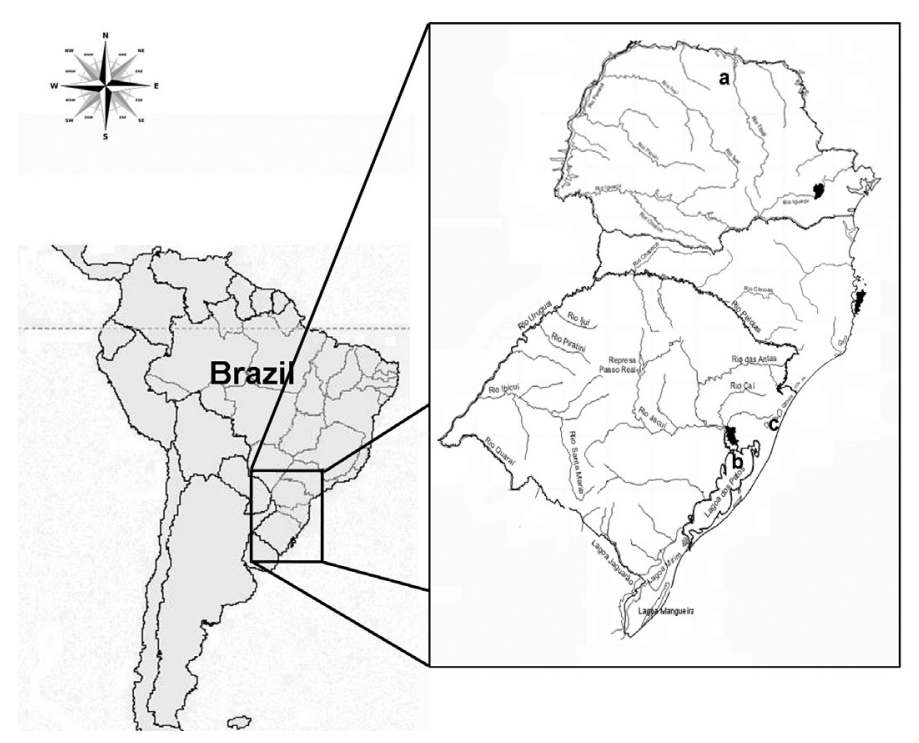

Figure 1. Collection sites of studied specimens. Map of Brazil showing the Paraná, Santa Catarina and Rio Grande do Sul states in the selected area (right side). Hydrographic map showing the (a) Tibagi river basin; (b) Hydrographic systems of Laguna dos Patos; and (c) Tramandaí river basin. 


\section{Conventional staining}

Metaphasic chromosomes were obtained by the air drying technique (Bertollo et al., 1978 ) and lymphocyte culture (Fenocchioand Bertollo, 1988) and stained with 5\% Giemsa in phosphate buffer ( $\mathrm{pH}$ 6.8) The chromosomes were organized as metacentric (m), submetacentric (sm), subtelocentric (st) and acrocentric (a) for the preparation of a karyogram. Chromosomes metacentric, submetacentric and subtelocentric were considered as biarmed and acrocentric as uniarmed to determine the fundamental number (FN).

\section{Chromosome banding}

Active nucleolar organizer regions (NORs) were detected by silver nitrate staining (Howell and Black, 1980). The distribution of heterochromatin was analyzed by Giemsa Cbanding after treatments with $0.1 \mathrm{M} \mathrm{HCl}, \mathrm{Ba}(\mathrm{OH})_{2}$ and $2 \mathrm{X}$ SSC (Sumner, 1972). The GC- and AT-rich bands were detected with chromomycin $\mathrm{A}_{3}\left(\mathrm{CMA}_{3}\right)$ and 4'-6-diamino-2-phenylindole (DAPI), respectively, according to Schweizer (1976). The slides were stained with $0.5 \mathrm{mg} / \mathrm{mL}$ $\mathrm{CMA}_{3}$ for $1 \mathrm{~h}$, washed in distilled water and sequentially stained with $2 \mu \mathrm{g} / \mathrm{mL}$ DAPI for 15 min. Slides were mounted with a medium composed of glycerol/McIlvaine buffer ( $\mathrm{pH} 7.0)$ $1: 1$, plus $2.5 \mathrm{mM} \mathrm{MgCl}_{2}$.

\section{Fluorescence in situ hybridization}

The in situ hybridization procedure was performed according to Swarça et al. (2001). The 18S rDNA probe of Prochilodus argenteus Agassiz, 1829 (Hatanaka and Galetti, 2004) was labeled with biotin-14-dATP by nick translation. Slides were treated with $30 \mu \mathrm{L}$ hybridization mixture containing $4 \mu \mathrm{L} 100$ ng labeled probe, $15 \mu \mathrm{L} 50 \%$ formamide, $6 \mu \mathrm{L} 50 \%$ polyethylene glycol, $3 \mu \mathrm{L} 20 \mathrm{X}$ SSC, $1 \mu \mathrm{L} 100 \mathrm{ng}$ calf thymus DNA, and $1 \mu \mathrm{L} 10 \%$ SDS. The material was denatured at $90^{\circ} \mathrm{C}$ for $10 \mathrm{~min}$, and hybridization was performed overnight at $37^{\circ} \mathrm{C}$ in a humidified chamber. Post-hybridization washes were carried out in 2X SSC, $20 \%$ formamide in $0.1 \mathrm{X} \mathrm{SSC}, 0.1 \mathrm{X} \mathrm{SSC}$ and $4 \mathrm{X} \mathrm{SSC} / 0.2 \%$ Tween 20 , all at $42^{\circ} \mathrm{C}$. The probe was detected with a solution of $5 \%$ BSA and FITC-conjugated avidin (50:0.5, v:v). The post-detection washes were performed in $4 \mathrm{X} \mathrm{SSC} / 0.2 \%$ Tween 20 at room temperature. Slides were mounted with 25 $\mu \mathrm{L}$ a medium composed of $23 \mu \mathrm{L}$ DABCO solution (1,4-diaza- bicyclo (2.2.2)-octane (2,3\%), $20 \mathrm{mM}$ Tris $\mathrm{HCl}, \mathrm{pH} 8.0,(2 \%)$ and glycerol (90\%), in distilled water), $1 \mu \mathrm{L} 2 \mu \mathrm{g} / \mathrm{mL}$ DAPI and $1 \mu \mathrm{L} 50 \mathrm{mM} \mathrm{MgCl}$.

All the images were acquired with a Leica DM 4500 B microscope equipped with a DFC 300FX camera and Leica IM50 4.0 software, and optimized for best contrast and brightness with iGrafx Image software.

\section{RESULTS}

\section{Hyphessobrycon anisitsi (Eigenmann, 1907)}

H. anisitsi showed a chromosome number of $2 \mathrm{n}=50$, where the karyotype formula is $18 \mathrm{~m}+10 \mathrm{sm}+6 \mathrm{st}+16 \mathrm{a}$ and the fundamental number equal 84 (Figure 2a). C-banding dem- 
onstrated a distribution of heterochromatin in the pericentromeric region of all chromosomes, in the terminal region of the long arm of some chromosomes and also as blocks more evident in the terminal region of the short arm of two metacentric chromosome pairs and on the long arm of one acrocentric chromosome pair, probably pair 23 (Figure 3a).
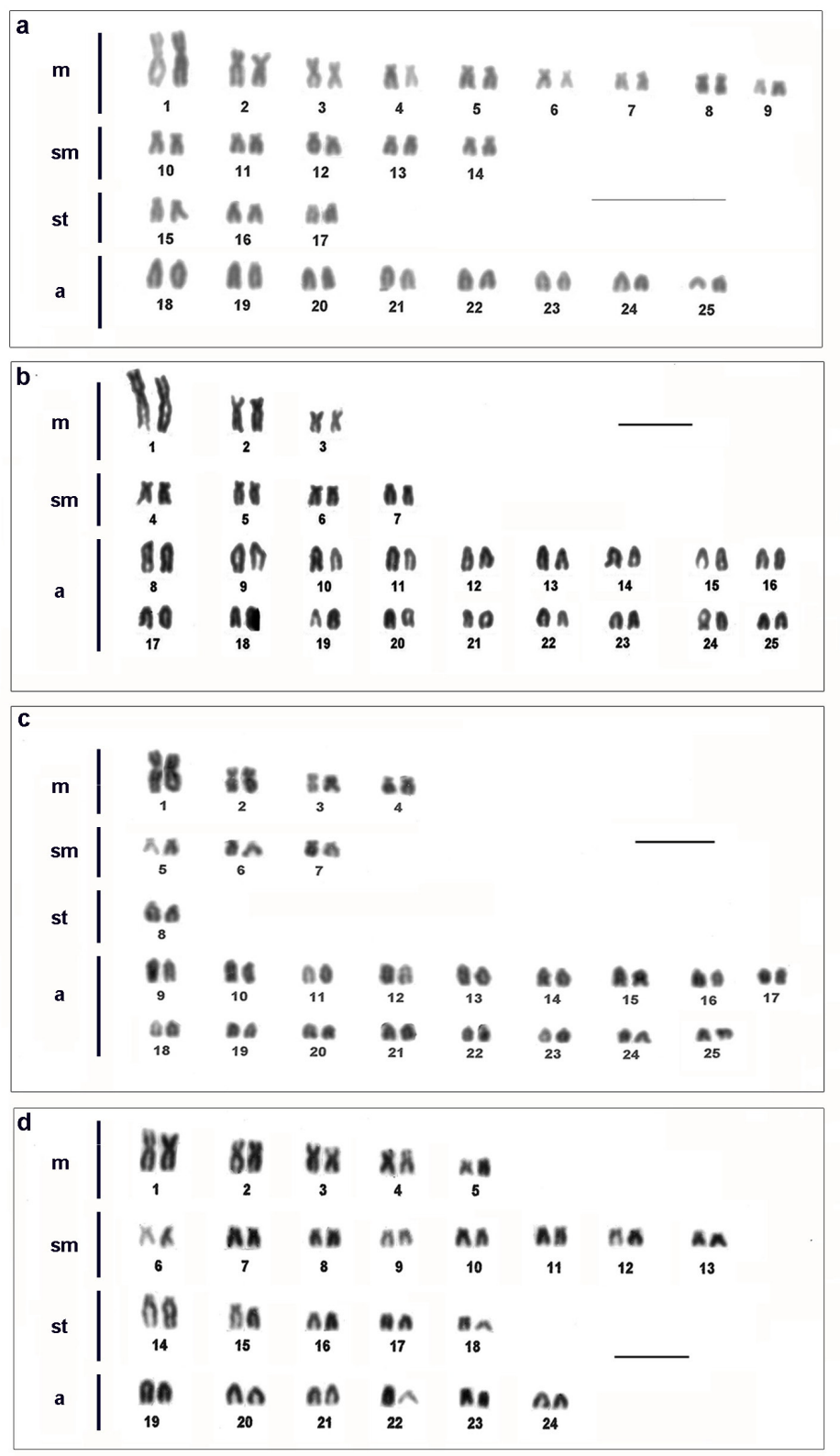

Figure 2. Karyograms of studied specimens: (a) Hyphessobrycon anisitsi; (b) Hyphessobrycon luetkenii; (c) Deuterodon stigmaturus; and (d) Astyanax eigenmanniorum. Bars $=10 \mu \mathrm{m}$. 

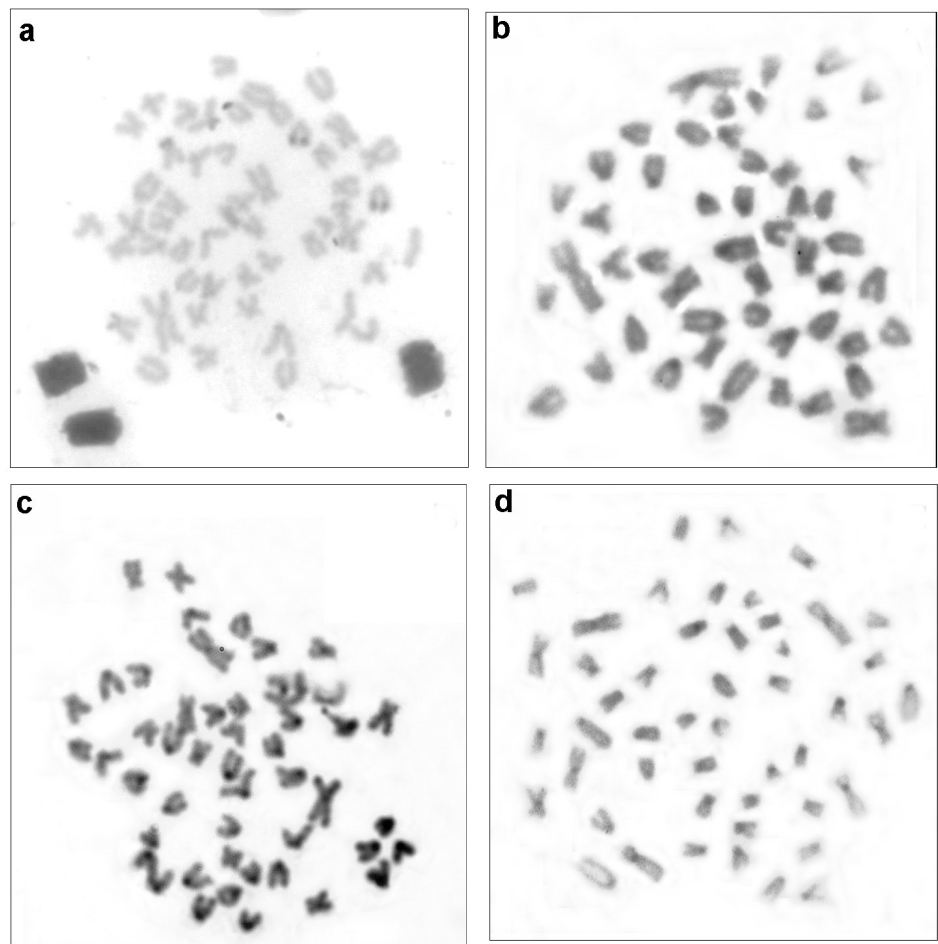

Figure 3. Metaphases of studied specimens after C-banding: (a) Hyphessobrycon anisitsi. Note pericentromeric C-bands and four chromosomes with terminal blocks (short arm of two metacentric chromosome pairs and on the long arm of one acrocentric chromosome pair); (b) Hyphessobrycon luetkenii; (c) Deuterodon stigmaturus; and (d) Astyanax eigenmanniorum. . Note the pericentromeric C-bands in most chromosomes.

NORs were observed in short arms of three chromosomes: on sixth metacentric pair and in one of homologues of pair 10 (Figure 4a). Using fluorochrome staining were found an intra- and interindividual variation, with 2 to 8 chromosomes showing $\mathrm{CMA}^{+} / \mathrm{DAPI}-$ signals (Figure 5a-d), confirmed by FISH with 18S rDNA probe, that showed 6 to 8 chromosomal marks (Figure 6a).

\section{Hyphessobrycon luetkenii (Boulenger, 1887)}

H. luetkenii, of the two hydrographic systems in the State of Rio Grande do Sul (RS), showed a chromosome number of $2 \mathrm{n}=50$, with the karyotype formula being $6 \mathrm{~m}+8 \mathrm{sm}+36 \mathrm{a}$, and the fundamental number equal 64 (Figure 2b). Heterochromatin was distributed in the pericentromeric region in the majority of chromosomes of the complement (Figure 3b).

All the specimens showed intra- and interindividual variation about NORs, markings were observed on the short arms of 2 to 9 acrocentric chromosomes (Figure 4b) After treatment with fluorochrome, were observed until 5 small sites $\mathrm{CMA}^{+} / \mathrm{DAPI}$ - in short arm of acrocentric chromosomes (Figure 5e). FISH with 18S rDNA probe showed until 12 chromosomes with ribosomal sites (Figure $6 b$ ). 

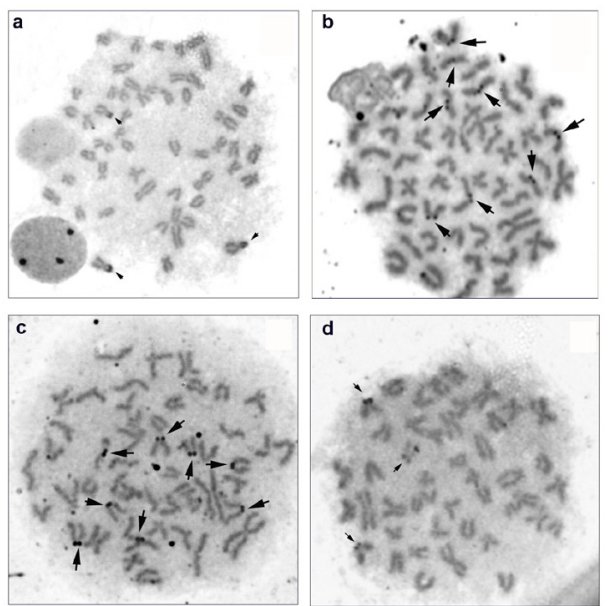

Figure 4. Metaphase chromosomes showing the Ag-NOR sites: (a) Hyphessobrycon anisitsi; (b) Hyphessobrycon luetkenii; (c) Deuterodon stigmaturus; and (d) Astyanax eigenmanniorum. Arrows indicate the NORs.
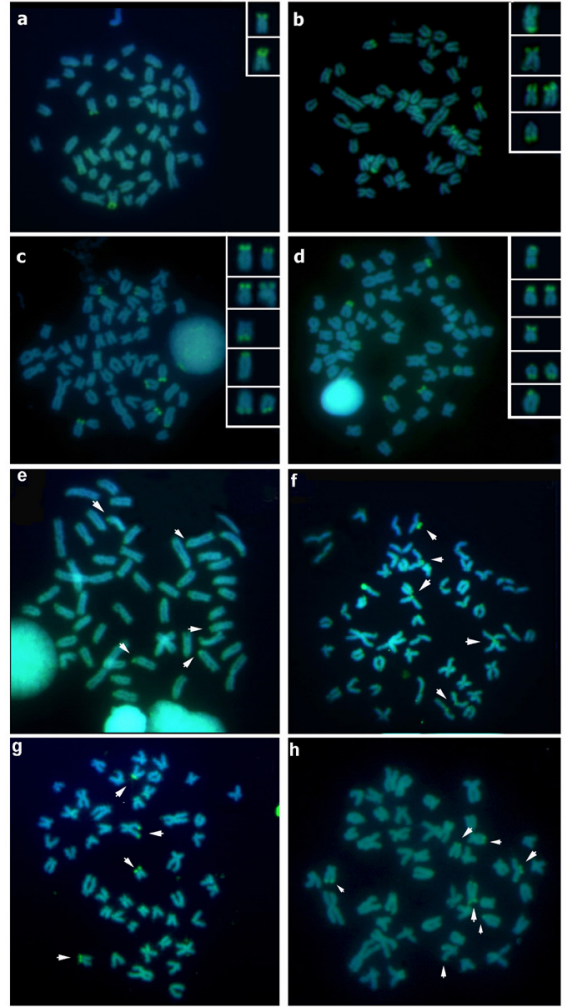

Figure 5. CMA/DAPI banding in four species of incertae sedis group: (a-d) Metaphases of Hyphessobrycon anisitsi showing the $\mathrm{CMA}^{+} / \mathrm{DAPI}{ }^{-}$sites. The chromosomes bearing GC-rich sites are shown in the box. Note the site variation among different metaphases. (e) Hyphessobrycon luetkenii; (f) Deuterodon stigmaturus; (g-h) Astyanax eigenmanniorum. Note the variation in numbers of $\mathrm{GC}$-rich sites. Arrows indicate the $\mathrm{CMA}^{+} / \mathrm{DAPI}^{-}$sites. 

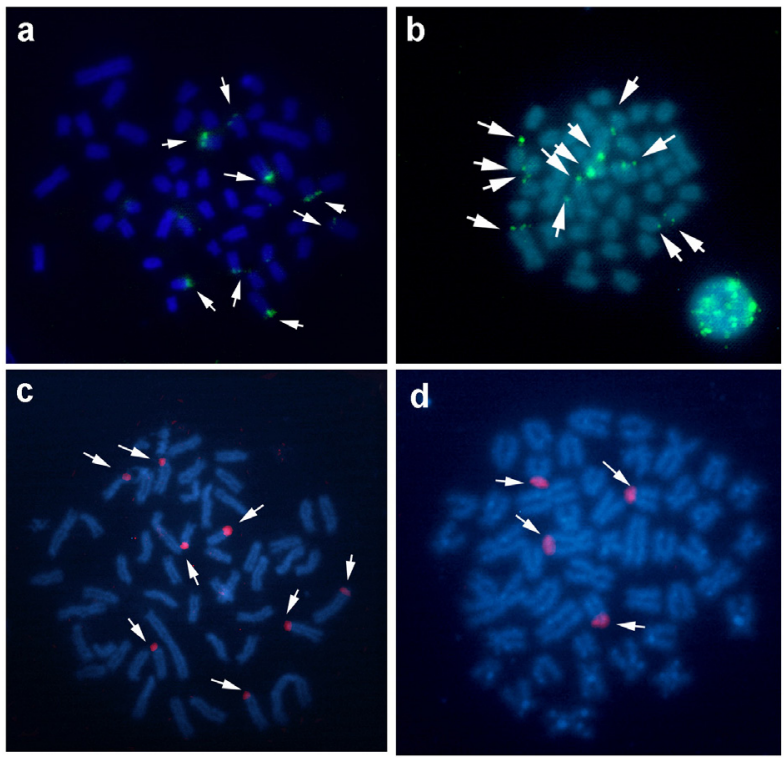

Figure 6. Fluorescence in situ hybridization with $18 \mathrm{~S}$ rDNA probe. (a) Hyphessobrycon anisitsi, (b) Hyphessobrycon luetkenii; (c) Deuterodon stigmaturus; (d) Astyanax eigenmanniorum. Arrows indicate the ribosomal sites.

\section{Deuterodon stigmaturus (Gomes, 1947)}

D. stigmaturus showed $2 \mathrm{n}=50$ chromosomes, along with the karyotype formula $8 \mathrm{~m}$ $+6 \mathrm{sm}+2 \mathrm{st}+34 \mathrm{a}$ and a fundamental number of 66 (Figure 2c). Heterochromatin appeared weakly present in the pericentromeric regions of all the complement (Figure 3c).

NORs showed intra- and interindividual variations, observed like small sites in short arms of 4 to 7 acrocentric chromosomes (Figure 4c). Fluorochrome staining showed small signals $\mathrm{CMA}^{+} / \mathrm{DAPI}-$ in short arms of acrocentric chromosomes (Figure 5f). In FISH with $18 \mathrm{~S}$ rDNA probe, 8 acrocentric chromosomes with fluorescence signals in terminal regions of the short arm were observed (Figure 6c).

\section{Astyanax eigenmanniorum (Cope, 1894)}

A. eigenmanniorum showed $2 \mathrm{n}=48$ chromosomes, distributed as $10 \mathrm{~m}+16 \mathrm{sm}+10 \mathrm{st}+$ 12a, with a fundamental number of 84 (Figure 2d). C-banding in this species demonstrated the weak presence of heterochromatin in the pericentromeric region of all chromosomes (Figure 3d).

All metaphases showed three subtelocentric chromosomes carrying the AgNOR in the short arm (Figure 4d). Using staining with fluorochrome $\mathrm{CMA}_{3}$ and DAPI can also be observed an interindividual variation in relation to positive signals $\mathrm{CMA}_{3}$. In an individual four chromosomes with markings $\mathrm{CMA}^{+} / \mathrm{DAPI}$, in short arms of three medium subtelocentrics and in the long arm of a large metacentric were observed (Figure 5g), and in the other analyzed specimens a large number of chromosomes with terminal $\mathrm{CMA}^{+} / \mathrm{DAPI}^{-}$marks in long and/or short arms were observed (Figure 5h). FISH with $18 \mathrm{~S}$ rDNA probe showed a interindividual variation of 3 to 4 ribosomal sites (Figure 6d). 
The results obtained for the four species are summarized in Table 1.

\begin{tabular}{|c|c|c|c|c|c|c|c|}
\hline Species & $2 \mathrm{n}$ & Karyotype formula & $\mathrm{FN}$ & C banding & Ag-NOR & CMA/DAPI & FISH \\
\hline Hyphessobrycon anisitsi & 50 & $18 m+10 s m+6 s t+16 a$ & 84 & $\begin{array}{l}\text { Pericentromeric, terminal, } \\
\text { some blocks more evident }\end{array}$ & 3 & $\begin{array}{l}\text { Inter- and } \\
\text { intraindividual variation }\end{array}$ & Variation \\
\hline Hyphessobrycon luetkenii & 50 & $6 m+8 s m+36 a$ & 64 & Pericentromeric & $2-9$ & 5 sites & 12 sites \\
\hline Deuterodon stigmaturus & 50 & $8 m+6 s m+2 s t+34 a$ & 66 & Pericentromeric & 4-7 & 5 sites & 8 sites \\
\hline Astyanax eigenmanniorum & 48 & $10 m+16 s m+10 s t+12 a$ & 84 & Pericentromeric & 3 & Interindividual variation & Variation \\
\hline
\end{tabular}

\section{DISCUSSION}

In the present study, the representatives of Deuterodon stigmaturus and Astyanax eigenmanniorum studied had been collected in the type locality (topotype), and this was the first cytogenetics report for D. stigmaturus and Hyphessobrycon luetkenii.

The diploid chromosome number of 50 was observed for Hyphessobrycon anisitsi, $H$. luetkenii and Deuterodon stigmaturus, corresponding to the most frequent value for the family Characidae, present in other populations and species previously studied from the genus Hyphessobrycon, such as $H$. anisitsi of the populations in the Piracuama and Perdizes rivers (Centofante et al., 2003a), H. herbertaxelrodi (Géry, 1961) and H. flammeus (Myers, 1924, Arefjev, 1990), and also in other species of the group, for example, of the genera Moenkhausia (Foresti et al., 1989; Portela-Castro and Júlio Jr., 2002), Oligosarcus (Martinez et al., 2004; Kavalco et al., 2005; Rubert and Margarido, 2007), Salminus (Margarido and Galetti Jr., 1999; Souza et al., 2008) and Astyanax (Pacheco et al., 2001; Kavalco and Moreira-Filho, 2003; Pamponet et al., 2008), among others. In the genus Deuterodon, only Deuterodon pedri (Eigenmann, 1908) has been studied cytogenetically, and the chromosome number observed was also 50 (Portela et al., 1988).

An interesting observation in D. stigmaturus and H. luetkenii was the presence of a large number of acrocentric chromosomes, an uncommon characteristic among the representatives of this group of fish, but which has also been observed in Ctenobrycon hauxwellianus (Cope, 1870, Carvalho et al., 2002), Deuterodon pedri (Portela et al., 1988) and Exodon paradoxus (Müller and Troschel, 1844, Venere et al., 1997). Portela et al. (1988) suggested that the ancestral karyotype of the old subfamily Tetragonopterinae would be $2 \mathrm{n}=50$ meta- and submetacentric chromosomes, and therefore, the species with the greater number of acrocentric chromosomes can be considered to be more derived, due to the accumulation of chromosomal rearrangements along the process of karyotype differentiation for these populations.

Hyphessobrycon anisitsi of Cambé stream showed $18 \mathrm{~m}+10 \mathrm{sm}+6 \mathrm{st}+16 \mathrm{a}$, a karyotype formula very different from that of the populations analyzed by Centofante et al. (2003a) who found $6 \mathrm{~m}+16 \mathrm{sm}+12 \mathrm{st}+16 \mathrm{a}$ for $\mathrm{H}$. anisitsi of Piracuama and Perdizes rivers, but the FN of 84 was the same, because the number of chromosomes with one and two arms was identical. The variation in chromosome types observed between the populations of Cambé stream and those examined by Centofante et al. (2003a), could be due to the occurrence of pericentric inversion in metacentric chromosomes, giving rise to submeta- and subtelocentric chromosomes, suggesting a divergent karyotype evolution in this group of fish.

Astyanax eigenmanniorum showed $2 \mathrm{n}=48$ chromosomes, where this diploid number has been found in other species such as: A. fasciatus (Cuvier, 1819, Pazza et al., 2006), A. 
parahybae (Eigenmann, 1908, Centofante et al., 2003b; Kavalco and Moreira-Filho, 2003), and some populations of A. scabripinnis (Jenyns, 1842, Fernandes and Martins-Santos, 2003; Malacrida et al., 2003; Vicari et al., 2008). Another population of Astyanax eigenmanniorum, from Caetano stream, Uberlandia/MG, analyzed by Torres-Mariano and Morelli (2008), showed a formula of $14 \mathrm{~m}+18 \mathrm{sm}+10 \mathrm{st}+6 \mathrm{a}$, constituted by a greater number of meta- and submetacentric chromosomes (32), compared with the results obtained in this study (26 chromosomes). Torres-Mariano and Morelli (2008) also found 0 to 2 B chromosomes which were not observed in the population studied here. In Astyanax eigenmanniorum of Laguna dos Patos, the first metacentric pair did not show a size much greater than that of the other chromosomes of the complement, which is a characteristic that is shared by many characids and that was observed in the population studied by Torres-Mariano and Morelli (2008).

In relation to heterochromatin, the population of Astyanax eigenmanniorum of Laguna dos Patos showed the weak presence of heterochromatin in the pericentromeric region of all chromosomes, while A. eigenmanniorum of Caetano stream/MG displayed heterochromatin distributed in the terminal and/or centromeric regions (Torres-Mariano and Morelli, 2008). Observing the karyotypic differences found between the population of Astyanax eigenmanniorum in the present study and the population of the Caetano stream /MG suggests that the latter probably belongs to a different species, because the karyotype differences found between these two populations corroborate what was described by Lima et al. (2003), limiting the occurrence of A. eigenmanniorum to the southern region of Brazil. Confirming this fact, Fauaz et al. (1994) recorded karyotype data for A. eigenmanniorum of Grande River/MG; however, the specimens of this population were recently identified as being A. bockmanni (Vari and Castro, 2007).

Deuterodon stigmaturus and Hyphessobrycon luetkenii also displayed heterochromatin distribution with weak staining in the pericentromeric region of all chromosomes.

Hyphessobrycon anisitsi showed a pattern of heterochromatin distribution completely different from that of the 3 other species studied, showing more abundant heterochromatin in the pericentromeric and terminal regions in the majority of chromosomes of the karyotype, where this was present in terminal blocks more evident in 3 chromosome pairs: 3 and 6 , in the short arm, and in the long arm of chromosome 23. Centofante et al. (2003a) also observed heterochromatic terminal blocks in populations of $H$. anisitsi of the Perdizes and Piracuama rivers, in various chromosomes, including chromosomes 2,6 and 21, which could be similar to chromosomes 3, 6 and 23 observed in the present study, and which could be considered chromosome markers for this species.

According to Margarido and Galetti Jr. (1999), the pattern of heterochromatin distribution is useful in the characterization and differentiation of some species. In the present study, it can be seen that the 3 species that had the same heterochromatin pattern belong to the hydrographic basins of the same region, while $H$. anisitsi, which belongs to the basin of Tibagi river/PR, has a totally different pattern of heterochromatin distribution.

Multiple NORs were observed in four studied species. Deuterodon stigmaturus and Hyphessobrycon luetkenii showed little AgNORs sites, usually present in a large amount and on short arms of acrocentric chromosomes, varying both inter and intra individually. FISH with 18S rDNA, proved the lot and location of AgNORs, being found eight chromosomes bearing these ribosomal sites in D. stigmaturus and 12 small sites in H. luetkenii.

No data were found on chromosome banding for the genus Deuterodon and for $\mathrm{Hy}$ phessobrycon luetkenii, however, the presence of multiple NORs is very common in the family Characidae, for example, occurs in species of the genus: Astyanax (Mizoguchi and Mar- 
tins-Santos, 1998; Kavalco and Moreira-Filho, 2003; Pazza et al., 2006), Hyphessobrycon (Centofante et al., 2003a), Piabina (Portela et al., 1988; Peres et al., 2008), among others.

AgNORs GC-rich are also common in the family of Characidae and present in Salminus hilarii (Valenciennes, 1850) and S. brasiliensis (Cuvier, 1816, Margarido and Galetti Jr., 1999), Moenkhausia sanctaefilomenae (Steindachner, 1907), M. intermedia (Eigenmann, 1908), Hemigrammus marginatus (Ellis, 1911, Portela-Castro and Júlio Jr., 2002).

While D. stigmaturus and H. lutkenii showed a conservation in AgNORs, $\mathrm{CMA}_{3}$ and 18S rDNA sites, the two other species showed an intra- and interindividual variation of these sites. H. anisitsi and A. eigenmanniorum always showed 3 chromosomes with AgNORs, which were also related to the $18 \mathrm{~S}$ rDNA and $\mathrm{CMA}_{3}$ sites. However, in these species an interindividual variation of these latter sites can be observed, characterizing these populations as polymorphic for the number and chromosomal distribution of $\mathrm{CMA}_{3}$ and ribosomal sites. Interindividual variation of ribosomal DNA has been found in other species and populations of neotropical fish studied, as Astyanax scabripinnis (Ferro et al., 2000; Mantovani et al., 2005), Serrasalmus (La Cepède, 1803, Nakayama, 2007), Squalius alburnoides (Steindachner, 1866) and S. pyrenaicus (Günther, 1868, Gromicho et al., 2005).

The polymorphism observed in $H$. anisitsi and A. eigenmanniorum, in this study, can be associated to a very small size of sites of ribosomal DNA, that might hinder the detection of the hybridization signals corresponding to the chromosomes. Another hypothesis is the idea that real differences between individuals and populations may occur with the ribosomal sites (Ferro et al., 2000; Gromicho et al., 2005).

Cytogenetic analyses performed in four species of Characidae, showed a variation in relation to chromosomal macro- and microstructure. In two species, $H$. luetkenii and $D$. stigmaturus a constant cytogenetic pattern in relation to the other two species, that showed a karyotipical variability was observed.

The present study contributes to the accumulation of cytogenetic information on the family Characidae, principally with the cytogenetic characterization of topotypes and demonstrating that taxonomically well-defined species, such as Hyphessobrycon luetkenii from different hydrographic basins, has a stable karyotype. However, H. anisitsi which is not well delimited taxonomically, shows karyotype differences between the populations previously investigated and that in the present study, which could mean the occurrence of more than one species, thereby indicating the need for a taxonomic revision for this group of fish.

\section{ACKNOWLEDGMENTS}

The authors are grateful to CAPES, CNPq and Fundação Araucária for financial support and to Dr. Luiz R. Malabarba for the identification of the studied species. We are also thankful to Dr. Albert Leyva for his help in the preparation of the manuscript.

\section{REFERENCES}

Arefjev VA (1990). Problems of karyotypic variability in the family Characidae (Pisces, Characiformes) with the description of somatic karyotypes for six species of tetras. Caryologia 43: 305-319.

Bertollo LAC, Takahashi CS and Moreira-Filho O (1978). Cytotaxonomic considerations on Hoplias lacerdae (Pisces, Erythrinidae). Rev. Bras. Genet. 1: 103-120.

Capistano TG, Castro ALBP and Julio HF Jr (2008). Chromosome divergence and NOR polymorphism in Bryconamericus aff. iheringii (Teleostei, Characidae) in the hydrographic systems of the Paranapanema and Ivai Rivers, Paraná 
Brazil. Genet. Mol. Biol. 31: 203-207.

Carvalho ML, Oliveira C and Foresti F (2002). Cytogenetic analysis of five species of the subfamily Tetragonopterinae (Teleostei, Characiformes, Characidae). Caryologia 55: 181-188.

Centofante L, Bertollo LAC, Miyazawa CS and Moreira-Filho O (2003a). Chromosomal differentiation among allopatric populations of Hyphessobrycon anisitsi (Pisces, Tetragonopterinae). Cytologia 68: 283-288.

Centofante L, Bertollo LAC, Justi AJ and Moreira-Filho O (2003b). Correlation of chromosomal and morphologic characters in two Astyanax species (Teleostei, Characidae). Ichthyol. Explor. Freshwaters 14: 361-368.

de Brito Portela-Castro AL, Ferreira Julio JH and Belini NP (2000). New occurrence of microchromosomes B in Moenkhausia sanctaefilomenae (Pisces, Characidae) from the Parana River of Brazil: analysis of the synaptonemal complex. Genetica 110: 277-283.

Diniz D, Moreira-Filho O and Bertollo LA (2008). Molecular cytogenetics and characterization of a ZZ/ZW sex chromosome system in Triportheus nematurus (Characiformes, Characidae). Genetica 133: 85-91.

Fauaz G, Vicente VE and Moreira-Filho O (1994). Natural triploidy and B chromosomes in the neotropical fish genus Astyanax (Characidae). Braz. J. Genet. 17: 157-163.

Fenocchio AS and Bertollo LAC (1988). A simple method for fresh-water fish lynphocyte culture. Rev. Bras. Genet. 11: 847-852.

Fernandes CA and Martins-Santos IC (2003). Cytogenetic characterization of two populations of Astyanax scabripinnis (Pisces, Characiformes) of the Ivaí Basin PR Brazil. Cytologia 68: 289-293.

Ferro DA, Neo DM, Moreira-Filho O and Bertollo LA (2000). Nucleolar organizing regions, 18S and 5S rDNA in Astyanax scabripinnis (Pisces, Characidae): populations distribution and functional diversity. Genetica 110: 55-62.

Foresti F, Almeida-Toledo LF and Toledo SA (1989). Supernumerary chromosome system, C-banding pattern characterization and multiple nucleolus organizer regions in Moenkhausia sanctaefilomenae (Pisces, Characidae). Genetica 79: 107-114.

Gromicho M, Ozouf-Costaz C and Collares-Pereira MJ (2005). Lack of correspondence between CMA3-, Ag-positive signals and $28 \mathrm{~S}$ rDNA loci in two Iberian minnows (Teleostei, Cyprinidae) evidenced by sequential banding. Cytogenet. Genome Res. 109: 507-511.

Hashimoto DT, Gonçalves VR, Bortolozzi J, Foresti F, et al. (2008). First report of a B chromosome in a natural population of Astyanax altiparanae (Characiformes, Characidae). Genet. Mol. Biol. 31: 275-278.

Hatanaka T and Galetti PM (2004). Mapping of the 18S and 5S ribosomal RNA genes in the fish Prochilodus argenteus Agassiz, 1829 (Characiformes, Prochilodontidae). Genetica 122: 239-244.

Hattori RS, Daniel-Silva MFZ and Almeida-Toledo LF (2007). Karyotype characterization and gene mapping of 5S and 18S rDNA in three species of Oligosarcus (Teleostei: Characidae). Caryologia 60: 372-378.

Kantek DLZ, Noleto RB, Maurutto FAM, Bertollo LAC, et al. (2008). Cytotaxonomy of Astyanax (Characiformes, Characidae) from the Upper Iguaçu River Basin: confirmation of the occurrence of distinct evolutionary units. $J$. Fish Biol. 73: 2012-2020.

Kavalco KF and Moreira-Filho O (2003). Cytogenetical analyses in four species of the genus Astyanax (Pisces, Characidae) from Paraíba do Sul river basin. Caryologia 56: 453-461.

Kavalco KF, Pazza R, Bertollo LA and Moreira-Filho O (2005). Molecular cytogenetics of Oligosarcus hepsetus (Teleostei, Characiformes) from two Brazilian locations. Genetica 124: 85-91.

Levan A, Fredga K and Sandberg AA (1964). Nomenclature for centromeric position on chromosomes. Hereditas 52: 201-220.

Lima FCT, Malabarba LR, Buckup PA, Silva JFP, et al (2003). Genera Incertae sedis in Characidae. In: Check List of the Freshwater Fishes of South and Central America (Reis RE, Kullander SO and Ferraris JRCJ, eds.). EDIPUCRS, Porto Alegre.

Margarido VP and Galetti PM Jr (1999). Heterochromatin patterns and karyotype relationships within and between the genera Brycon and Salminus (Pisces, Characidae). Genet. Mol. Biol. 22: 357-361.

Martinez ERM, Oliveira C and Júlio HF Jr (2004). Cytogenetic analysis of species of the genera Acestrorhynchus, Oligosarcus and Rhaphiodon (Teleostei: Characiformes). Caryologia 57: 294-299.

Morelli S, Bertollo LAC, Foresti F, Moreira-Filho O, et al. (1983). Cytogenetic considerations on the genus Astyanax (Pisces, Characidae) I. Karyotypic variability. Caryologia 36: 235-244.

Nirchio M, Oliveira C, Ferreira IA, Granado A, et al. (2007). Extensive polymorphism and chromosomal characteristics of ribosomal DNA in the characid fish Triportheus venezuelensis (Characiformes, Characidae). Genet. Mol. Biol. 30: $25-30$.

Pacheco RB, Giuliano-Caetano L and Dias AL (2001). Cytotypes and multiple NOR in an Astyanax altiparanae population (Pisces, Tetragonopterinae). Chromosome Sci. 5: 109-114.

Paintner-Marques TR, Giuliano-Caetano L and Dias AL (2002). Karyotypic diversity in a Bryconamericus aff. exodon 
population (Characidae, Tetragonopterinae). Cytologia 67: 397-402.

Pamponet VCC, Carneiro PLS, Affonso PRAM, Miranda VS, et al. (2008). A multi-approach analysis of the genetic diversity in populations of Astyanax aff. bimaculatus Linnaeus, 1758 (Teleostei: Characidae) from Northeastern Brazil. Neotrop. Ichthyol. 6: 621-630.

Pazza R, Kavalco KF and Bertollo LA (2006). Chromosome polymorphism in Astyanax fasciatus (Teleostei, Characidae). 1. Karyotype analysis, Ag-NORs and mapping of the $18 \mathrm{~S}$ and $5 \mathrm{~S}$ ribosomal genes in sympatric karyotypes and their possible hybrid forms. Cytogenet. Genome Res. 112: 313-319.

Portela-Castro ALB and Júlio HF Jr (2002). Karyotype relationships among species of subfamily Tetragonopterinae (Pisces, Characidae): cytotaxonomy and evolution aspects. Cytologia 67: 329-336.

Portela ALBS, Galetti PM Jr and Bertollo LAC (1988). Considerations on the chromosome evolution of Tetragonopterinar (Pisces, Characidae). Braz. J. Genet. 11: 307-316.

Reis RE, Kullander SO and Ferraris JRCJ (2003). Check List of the Freshwater Fishes of South and Central America. EDIPUCRS, Porto Alegre.

Rosa R, Rubert M, Malabarba LR, Martins-Santos IC, et al. (2009). Cytogenetic analysis of Astyanax laticeps (Cope, 1894) (Ostariophysi: Characidae) from the laguna dos Patos system. Neotrop. Ichthyol. 7: 601-605.

Rubert M and Margarido VP (2007). Cytogenetic studies in three species of the genus Oligosarcus. Braz. Arch. Biol. Technol. 50: 127-135.

Schweizer D (1976). Reverse fluorescent chromosome banding with chromomycin and DAPI. Chromosoma 58: 307-324.

Souza IL, Santos-Silva LK, Venere PC and Moreira-Filho O (2008). Molecular cytogenetics of Salminus fish (Characiformes) based on 5S and 18S rRNA genes hybridization, fluorochrome staining and C-banding. Micron. 39: 1036-1041.

Sumner AT (1972). A simple technique for demonstrating centromeric heterochromatin. Exp. Cell Res. 75: 304-306.

Swarça AC, Cestari MM, Giuliano-Caetano L and Dias AL (2001). Cytogenetic characterization of the large South American siluriform fish species Zungaro zungaro (Pisces, Pimelodidae). Chrom. Sci. 5: 51-55.

Torres-Mariano AR and Morelli S (2008). B chromosomes in a population of Astyanax eigenmanniorum (Characiformes, Characidae) from the Araguari River Basin (Uberlândia, MG, Brazil). Genet. Mol. Biol. 31: 246-249.

Venere PC, Pfister SC, Moreira-Filho O and Galetti PM Jr (1997). Chromosomal characterization in Characinae and Cynopotaminae (Pisces, Characidae). Cytobios 92: 123-131.

Vicari MR, Noleto RB, Artoni RF, Moreira-Filho O, et al. (2008). Comparative cytogenetics among species of the Astyanax scabripinnis complex. Evolutionary and biogeographical inferences. Genet. Mol. Biol. 31: 173-179.

Wasko AP and Galetti PM Jr (1998). Karyotype diversity in the neotropical fish Bryconamericus (Characidae, Tetragonopterinae). Cytobios 94: 185-193. 